\author{
솔잎, 깻잎 및 녹차분말이 함유된 유화형 소시지 품질특성 \\ 김일석* . 진상근* . 하경희** . 류현지* . 박기훈* \\ 진주산업대학교 동물소재공학과*, 농촌진흥청 축산연구소**
}

\title{
Quality Characteristics of Emulsion-Type Sausage Containing Pine Needle, Perilla Leaves and Green Tea Powder
}

\author{
I. S. Kim*, S. K. Jin*, K. H. Hah**, H. J. Lyou* and K. H. Park* \\ Department of Animal Resources Technology, Jinju National University*, \\ National Livestock Research Institute**
}

\begin{abstract}
This study was carried out to investigate the effects of addition of functional material(T1; pine needle powder, $0.4 \%$, T2; perilla leaves powder, $0.4 \%$, T3; green tea powder, $0.4 \%$ ) on the quality characteristics of emulsion-type sausages. The samples were stored at $9 \pm 1{ }^{\circ} \mathrm{C}$ for 40 days and analyzed with an interval of 10 days. The $\mathrm{pH}$ of all emulsion-type sausages increased as storage period increased. Water holding capacity(WHC) of all treatments were slightly increased as storage period increased and rapidly decreased on 40 days of storage. In texture analysis, hardness, chewiness, gumminess and brittleness were increased with storage in all treatments group. TBARS values of T3 was lower than those of other treatments at 1 days of storage, while that was the slightly higher in $\mathrm{T} 4$ at 40 day of storage. The $\mathrm{L}^{*}$ values was decreased as storage period increased. The $\mathrm{a}^{*}$ values was highest in $\mathrm{C}$, while it was the lowest in $\mathrm{T} 2$ and T3. The residual nitrite content of all samples were in very safe range during the whole storage period. During the storage period 40 days, the Lactobacilli spp. of $\mathrm{C}$ were higher $\left(10^{7} \mathrm{CFU} / \mathrm{g}\right)$ than those of 3 treatments. In sensory evaluation, the score of overall acceptability were higher in the order of $\mathrm{C}(5.5 \sim 6.5)$ $>\mathrm{T} 1(4.8 \sim 6.0)>\mathrm{T} 2(4.8 \sim 5.8)>\mathrm{T} 3(4.3 \sim 4.8)$. In the manufacture of functional sausage containing pine needle, perilla leaves and green tea powder, further studied are needs on addition type/ratio of functional materials and the use of added spices.
\end{abstract}

(Key words : Quality characteristics, Emulsion-type sausages, Functional material)

\section{I. 서 론}

건강 지향적인 식품에 대한 소비자들의 관심 과 요구 증대에 의해 기능성 식품의 개발이 매 우 활발하게 이루어지고 있고, 섭취 시 질병예 방이나 건강증진에 유익한 효과가 있는 물질들 에 대한 탐색과 연구 결과로써 많은 기능성 제 품류들이 상품화되어 유통되고 있다. 최근 들 어, 식물성 식품을 건강식품의 소재로 활용하
기 위한 연구가 많이 이루어지고 있으며(Park 등, 2002), 또한 식물체 추출성분에 대한 식품 관련 산업과 의학분야에서 실용화 시도와 연구 대상으로 많은 관심이 집중되고 있다(Yoon 등, 1977).

솔잎은 민간요법에서 중풍을 예방하고 신경 통, 관절염, 동맥경화, 고혈압, 당뇨병과 같은 노화질환을 예방하는 효능(Moon 등, 1993)과 흰쥐에서의 카드뮴 독성의 해독(이와 박, 1996),

Corresponding author:S. K. Jin, Department of Animal Resources Technology, Jinju National University, Jinju, 660-758, Korea. Tel : 82-55-751-3283, Fax : 82-55-758-1892, E-mail : skjin@jinju.ac.kr 
체내 지방저하 효과(김과 김, 1999 ; 이와 최, 2000 ), 항산화작용(김 등, 2002; 김과 김, 1999 ; 백 등, 1991; 오 등, 2004; 이, 2003; 현 등, 2003), 아질산염 소거작용(김 등, 2002; 홍 등, 2004), 항암(Choi, 1991) 및 항균작용(Choi 등, 1997) 등의 효과가 있다고 보고되어 건강보조 식품으로도 널리 응용(Park, 1984)되고 있다.

깻잎에 관한 주요 연구들로는 들깻잎에서 동 정된 phytol과 eicosatrienoic acid의 위암세포에 서의 암세포 성장 억제효과(Lee 등, 1999), 메탄 올 추출물의 항돌연변이 효과와 과산화지질 생 성 억제 작용(Toyoda 등, 1997), Perilla속 식물 로부터 항산화제들의 분리 및 특성(Tada 등, 1996) 등이 있다. 들깨는 Linoleic acid가 다량 함유되어 혈압저하, 혈전증 개선, 암세포 증식 억제 등의 효과가 있으며(Park 등, 2001), 그 잎 에 함유되어 있는 식이섬유소는 당뇨병 및 비 만예방, 항균, 항암효과가 있는 것으로 보고 (Mercurio와 Behm, 1981)되었다.

녹차의 주요 생리활성물질은 polyphenol의 일 종인 catechin으로 녹차 polyphenol 함량의 약 $70 \%$ 이상을 차지하며(Khokhar과 Magnusdottir, 2002), 종류로는 flavonoiddhk 이의 유도물질인 flavanol, flavanones, antocyanindins, flavones, poliyphenolic acid 등이 있다(Graham, 1992). 녹 차의 유용성분은 항산화작용(김 등, 2004; Robak 과 Gryglewski, 1998)과 항균력(Shi, 2002), 콜레 스테롤 저하효과(Yang과 Koo, 1997; 진 등, 2004)가 있고, 최근 인체 연구에서 암 예방 효 과가 있음이 증명되었고(Yang과 Landau, 2002; 허 등, 2004) 또한 $\mathrm{LDL}$ 및 총콜레스테롤 수준 을 줄인다고(Davies 등, 2003) 보고되었고, 기능 성 식품의 소재로서 국수, 냉면, 식빵, 소시지, 육포 등에 널리 응용되고 있다(김 등, 2002; 박 등, 2002; 최 등, 2003).

본 연구는 생리기능성과 약리 효능이 있는 것으로 보고되고 있는 솔잎, 깻잎 및 녹차분말 육가공제품의 이용측면에서 이들을 각각 첨가 하여 유화형 소시지를 제조하고, 저장 중 물리 화학적, 미생물학적 및 관능적 품질특성을 비 교 조사하였다.

\section{II. 재료 및 방법}

\section{1. 공시재료 및 소시지 제조}

실험에 이용한 깻잎은 경남 진주시 재래시장 에서 구입한 것으로 깨끗하게 세척한 다음 -50 ${ }^{\circ} \mathrm{C}$ 에서 4 시간 급속 동결하고, $-80^{\circ} \mathrm{C}$ 에서 72 시 간 동안 동결건조한 후 완전 분말화 하여 사용 하였다. 솔잎 및 녹차분말은 $\mathrm{P}$ 회사에서 제조된 각각 그 함량이 $100 \%$ 인 국산품을 시중에서 구 입하여 사용하였다. 실험구는 Table 1에서 보는 바와 같이, 일반적인 유화형 소시지를 대조구 로 설정하고, 첨가되는 분말종류에 따라 3 가지 시험구(솔잎 $\mathrm{T} 1$, 깻잎 $\mathrm{T} 2$, 녹차 $\mathrm{T} 3$ )로 각각 처 리하였으며, 이때 첨가 비율은 모두 $0.4 \%$ 로 하 였다. 소시지 제조에 사용된 원료육은 돼지 뒷 다리부위를 구입하여 과도한 지방과 결체조직 을 제거한 후 직경 $5 \mathrm{~mm}$ 플레이트로, 등지방은 껍질을 제거한 후 직경 $3 \mathrm{~mm}$ 플레이트로 분쇄 한 후 사용하였다. 분쇄한 원료육을 silent cutter 에 넣은 후 저속으로 회전시키면서 배합비에 따라 첨가하였다. 유화과정 중 과도한 온도 상 승을 방지하기 위해 빙수(ice water)를 사용하였 고, 각종 첨가제를 혼합한 후 고속으로 회전하 면서 근원섬유단백질이 충분히 용출되었을 때, 지방을 넣고 유화를 시켰다. 유화물은 비통기 성 유색 화이브러스케이싱[직경 $46 \mathrm{~mm}$. (주)동 방무역]에 충전하여 오토클레이버(JS-AC-100, $100 \mathrm{~L}$, Johnsam Co.)에서 $78^{\circ} \mathrm{C}$ 에서 75 분간 탕침 가열한 후 흐르는 냉수에 냉각시켜 $9 \pm 1{ }^{\circ} \mathrm{C}$ 에서 40 일간 저장하면서 실험에 공시하였다.

\section{2. 분석방법}

(1) $\mathrm{pH}$

시료 $10 \mathrm{~g}$ 을 증류수 $90 \mathrm{ml}$ 와 함께 homogenizer (IKA, T25 Basic Malaysia)로 13,500 rpm에서 10 초간 균질하여 $\mathrm{pH}-\mathrm{meter}(\mathrm{Orion}$ 230A, USA)로 측정하였다.

(2) 보수력

마쇄한 시료를 $70^{\circ} \mathrm{C}$ 의 항온수조에서 30 분간 
Table 1. Formula of emulsion-type sausage

\begin{tabular}{lcccc}
\hline \multirow{2}{*}{ Ingredients } & \multicolumn{3}{c}{ Treatment $^{1)}$} \\
\cline { 2 - 5 } & $\mathrm{C}$ & $\mathrm{T} 1$ & $\mathrm{~T} 2$ & $\mathrm{~T} 3$ \\
\hline \hline Pork ham meat & 72.3 & 72.3 & 72.3 & 72.3 \\
Pork backfat & 11.2 & 11.2 & 11.2 & 11.2 \\
Ice & 13.8 & 13.8 & 13.8 & 13.8 \\
NPS & (1.4 & 1.4 & 1.4 & 1.4 \\
Phosphate & 0.2 & 0.2 & 0.2 & 0.2 \\
Sugar & 0.5 & 0.5 & 0.5 & 0.5 \\
Spice & 0.6 & 0.6 & 0.6 & 0.6 \\
Pine needle powder & & 0.4 & & \\
Perilla leaf powder & & & 0.4 & 0.4 \\
Green tea powder & & & 100.4 & 100.4 \\
\hline \multicolumn{1}{c}{ Total } & 100 & 100.4 & & \\
\hline
\end{tabular}

${ }^{1)} \mathrm{C}$ : commercial emulsion-type sausage, T1: $0.4 \%$ pine needle powder added on total content, T2: $0.4 \%$ Perilla leaves powder added on total content, T3: $0.4 \%$ green tea powder added on total content.

2) $\mathrm{NPS}\left(\mathrm{NaCl}: \mathrm{NaNO}_{2}\right)=99: 1$.

가열한 다음 냉각하여 $1,000 \mathrm{rpm}$ 에서 10 분간 원 심분리한 후 무게를 측정하였다. 별도로 동일 한 시료에 대하여 수분 함량을 dry oven $110^{\circ} \mathrm{C}$ 에서 건조시켜 측정하였다.

\section{(3) 조직감}

시료를 $19 \mathrm{~mm}$ core로 원통으로 자른 후 Instron(Model 3343, England)을 이용하여 검사 하였다. 이 때의 분석조건은 $50 \mathrm{~kg}$ load cell을 이용하여 시료를 2 번 물림으로 원래 높이의 약 $75 \%$ 까지 가압하고, 이 때의 chart speed와 crosshead의 speed는 각각 $200 \mathrm{~mm} / \mathrm{min}$ 이었다.

\section{(4) TBARS}

Buege와 Aust(1978)의 방법에 의해 시료 $5 \mathrm{~g}$ 에 butylated hydroxyanisole(BHA) $50 \mu$ 와 증류수 15 $\mathrm{ml}$ 을 첨가하여 균질화 시킨 후 균질액 $1 \mathrm{ml}$ 을 시험관에 넣고 여기에 $2 \mathrm{ml}$ thiobarbituric acid (TBA) / trichloroacetic acid(TCA) 혼합용액을 넣 어 완전히 혼합한 다음, $90^{\circ} \mathrm{C}$ 의 항온수조에서 15 분간 열처리한 후 냉각시켜 $3,000 \mathrm{rpm}$ 에서 10 분간 원심분리시켰다. 원심분리한 시료의 상층 을 회수하여 $531 \mathrm{~nm}$ 에서 흡광도를 측정하였다.
TBARS $=$ 흡광도 수치 $\times 5.88$

(5) 육색

육색은 시료를 상온에 30 분 방치한 다음 제 품을 $0.5 \mathrm{~cm}$ 두께로 잘라 육색을 측정하였다. 육색 측정 시 자른 단면은 Chromameter(Minolta Co. CR 400, Japan)를 이용하여 동일한 방법으 로 5 회 반복하여 측정하여, 명도(lightness)를 나 타내는 $\mathrm{L}^{*}$ 값, 적색도(redness)를 나타내는 $\mathrm{a}^{*}$ 값 과 황색도(yellowness)를 나타내는 $\mathrm{b}^{*}$ 값을 측정 하였다. 이때 표준색은 $\mathrm{L}^{*}$ 값이 $89.2, \mathrm{a}^{*}$ 값이 $0.921, \mathrm{~b} *$ 값이 0.783 인 표준색판을 사용하여 표 준화한 다음 측정하였다.

(6) 잔존 아질산염

소지지 내의 아질산염의 잔류량은 식품공전 상의 Diazotization 방법을 이용하여 측정하였다. 즉, 시료 $10 \mathrm{~g}$ 을 세절하고 $80^{\circ} \mathrm{C}$ 의 물과 고루 혼 합하여 $200 \mathrm{ml}$ 메스플라스크에 정량적으로 옮 긴 후 여기에 $0.5 \mathrm{~N} \mathrm{NaOH} 10 \mathrm{ml}$ 와 $12 \% \quad \mathrm{ZnSO}_{4}$ $10 \mathrm{ml}$ 를 넣고 섞어 $80^{\circ} \mathrm{C}$ 에서 20 분간 중탕한다. 중탕 후 냉각하고 ammonium acetate $20 \mathrm{ml}$ 를 넣 어 최종 부피를 $100 \mathrm{ml}$ 가 되게 한다. 내용물을 잘 혼합하여 10 분간 방치 후 여과하여 최초의 
여액 $20 \mathrm{ml}$ 는 버리고 맑은 여액을 시험용액으 로 한다. 따로 소시지 대신 증류수 $10 \mathrm{ml}$ 를 사 용하여 동일하게 조작한 것을 공시험용액으로 한다. 시험용액과 공시험 용액 $20 \mathrm{ml}$ 에 sulfanilamide solution $1 \mathrm{ml}$ 와 $\mathrm{N}-(1-\mathrm{Naphtyl})$ ethylenediamine solution $1 \mathrm{ml}$ 에 물을 넣어 $25 \mathrm{ml}$ 로 하고 잘 섞어 발색시켜 20 분간 방치 후 $540 \mathrm{~nm}$ 에서 흡광도를 측정한다. 미리 작성한 검량선에서 시험용액 $20 \mathrm{ml}$ 중의 아질산이온량 $(\mu \mathrm{g})$ 을 구하 고 검체중의 아질산 이온의 농도를 산출하였 다.

\section{(7) 미생물}

시료 $10 \mathrm{~g}$ 을 $1 \%$ peptone수 $90 \mathrm{ml}$ 에 넣고 균질 시킨 다음 $1 \mathrm{ml}$ 를 채취하여 준비된 $9 \mathrm{ml}$ peptone 수에 넣어 희석한 후, 총균수(Total bacterial counts)와 유산균(Lactobacilli spp.)은 미리 조제 한 Difco사의 plate counter agar와 MRS agar에 각각 배양하였다. 총 균수는 $32^{\circ} \mathrm{C}$ 에서, 유산균 은 $30^{\circ} \mathrm{C}$ 에서 각각 2 일 배양한 후 나타나는 colony의 수를 계수하였다.

\section{(8) 관능검사}

관능검사는 잘 훈련된 관능검사요원 10 명을 선발하여 각 시험구별로 9점 척도법을 실시하 였다. 각 검사 요인별로 낮음(bad or slight), 보 통(moderate), 강함(much or extreme)으로 나누어 각각 1 3, 4 6 그리고 7 9의 척도로 나누어 평 가토록 하였다. 즉, 육색은 1 2; 육색이 나쁨, $3 \sim 4$; 보통, 5 6; 육색이 좋음, 냄새와 풍미는 $1 \sim 2$; 약함, 3 4; 보통, 5 6; 강함, 연도는 1 2;
질김, 3 4; 보통, 5 6; 연함, 다즙성은 1 2; 다 즙성이 적음, 3 4; 보통, 5 6; 다즙성이 좋음, 기호도는 1 2; 좋지 않음, 3 4; 보통, 5 6; 좋음 으로 선택하게 하였다.

\section{3. 통계처리}

3 반복에 의해서 얻어진 결과는 $\mathrm{SAS}(1999)$ 의 GLM(General Linear Model) 방법으로 분석하였 고 처리 평균 간의 비교를 위해 Duncan의 Multiple Range Test를 이용하였다.

\section{III. 결과 및 고찰}

\section{1. $\mathrm{pH}$}

기능성 물질을 첨가한 유화형 소시지의 저장 기간 중 $\mathrm{pH}$ 변화는 Table 2와 같다. $\mathrm{pH}$ 는 육이 나 육제품의 연구에 기본이며 육제품의 품질을 좌우하는데 $\mathrm{pH}$ 의 고저에 따라 보수성 연도, 결 착력이 크게 영향을 받는 것으로 알려져 있다. 정 등(2003)에 따르면 깻잎 분말을 첨가하여 제 조한 소시지의 $\mathrm{pH}$ 는 첨가하지 않은 처리구에 비해 높게 나타났다고 하였으며, Nam 등(2000) 도 쑥과 솔잎 추출물을 첨가한 돈육 patty의 $\mathrm{pH}$ 가 대조구보다 높다고 하였는데, 이는 식물 에서 칼륨과 같은 무기질 함량이 높고 이들로 인하여 $\mathrm{pH}$ 가 높게 나타난다고 하였다. 하지만 본 실험에서는 처리구에 따른 $\mathrm{pH}$ 는 큰 차이를 보이지 않았으며, 다른 처리구에 비해 $\mathrm{T} 1$ 이 다 소 낮게 나타났고 $\mathrm{T} 2$ 와 $\mathrm{T} 3$ 가 높게 나타났다.

Table 2. Changes in $\mathrm{pH}$ of emulsion-type sausage with functional ingredients during storage at $9 \pm 1{ }^{\circ} \mathrm{C}$

\begin{tabular}{clllll}
\hline \multirow{2}{*}{ Treatment $^{1)}$} & \multicolumn{5}{c}{ Days } \\
\cline { 2 - 6 } & \multicolumn{1}{c}{1} & \multicolumn{1}{c}{20} & \multicolumn{1}{c}{30} & 40 \\
\hline \hline $\mathrm{C}$ & $5.80 \pm 0.02^{\mathrm{BCab}}$ & $5.76 \pm 0.03^{\mathrm{Cc}}$ & $5.88 \pm 0.10^{\mathrm{AB}}$ & $5.99 \pm 0.01^{\mathrm{Aa}}$ & $5.85 \pm 0.08^{\mathrm{BCb}}$ \\
$\mathrm{T} 1$ & $5.78 \pm 0.02^{\mathrm{Cb}}$ & $5.78 \pm 0.01^{\mathrm{Cbc}}$ & $5.88 \pm 0.04^{\mathrm{B}}$ & $5.93 \pm 0.03^{\mathrm{Aab}}$ & $5.89 \pm 0.03^{\mathrm{ABab}}$ \\
$\mathrm{T} 2$ & $5.83 \pm 0.04^{\mathrm{Ba}}$ & $5.82 \pm 0.04^{\mathrm{Bab}}$ & $5.79 \pm 0.08^{\mathrm{B}}$ & $5.95 \pm 0.03^{\mathrm{Aa}}$ & $5.95 \pm 0.01^{\mathrm{Aa}}$ \\
$\mathrm{T} 3$ & $5.85 \pm 0.02^{\mathrm{a}}$ & $5.85 \pm 0.01^{\mathrm{a}}$ & $5.76 \pm 0.02$ & $5.80 \pm 0.15^{\mathrm{b}}$ & $5.80 \pm 0.06^{\mathrm{b}}$ \\
\hline
\end{tabular}

\footnotetext{
1) Treatments are the same as described in Table 1.

A,B,C Means with different superscripts in the same row are significantly different $(\mathrm{P}<0.05)$.

a,b,c Means with different superscripts in the same column are significantly different $(\mathrm{P}<0.05)$.
} 
또한 저장기간이 증가함에 따라 모든 처리구에 서의 $\mathrm{pH}$ 는 증가하였으나 $\mathrm{T} 3$ 는 감소하는 경향 을 나타내었다. 저장기간에 따른 $\mathrm{pH}$ 의 증가는 아미노산이 분해되어 염기성기가 노출되기 때 문이라는 주장(Bartholmew와 Blumer, 1977)과 숙성 중에 단백질의 변화, 전해질 해리의 감소 및 암모니아의 생성 등에 의한 $\mathrm{pH}$ 의 증가 (Deymer와 Vendekerckhov, 1979) 때문이라는 설 명이 있다.

\section{2. 보수력}

기능성 물질을 첨가한 유화형 소시지의 저장 기간 중 보수력의 변화는 Table 3 과 같다. 육제 품에 물리적인 힘, 즉 절단, 분쇄, 압착, 동결, 해동, 열처리 등을 가했을 때 근육단백질의 수 분유지 능력은 처리 조건에 따라 변화하는데 보수력이란 식육을 가공 조리함에 있어 그 과 정 중에 식육중의 수분을 유지할 수 있는 능력 을 말하는 것으로서 식육 가공조리 제품에 있 어 탄력성과 다즙성에 기여하면 결착성과도 밀 접한 관련을 가지는 식육의 가공특성 중 가장 중요한 요소이다. 본 실험에서 처리구에 따른 경향은 나타나지 않았으며, 저장기간에 따라 모든 처리구에서 보수력이 다소 증가하였으나, 저장 40 일 보수력이 급격히 감소하였다. 육제 품을 오랫동안 저장할 경우 건조에 의해 수분 보유능이 감소하며, 단백질 변성에 의해 보수 력이 저하하게 되는데, 본 실험에서도 저장 40 일에 보수력이 급격히 감소하여 단백질 변성이 일어난 것으로 사료되며 또한 일반적으로 첨가 된 당류가 미생물에 의해 분해되어 유산이 생
성될 수 있는데 이 때 생성된 유산이 육의 $\mathrm{pH}$ 를 떨어뜨려 육단백질의 보수력을 저하시키는 것이 일반적인 경향이지만 본 연구결과에서는 $\mathrm{pH}$ 와의 관련성이 낮아 이에 대한 추가적인 기 초 연구가 더 필요하다고 판단되었다.

\section{3. 조직감}

기능성 물질을 첨가한 유화형 소시지의 저장 기간 중 조직감의 변화는 Table 4 와 같다. 육제 품의 조직감 측정은 육의 물리적인 특성을 측 정하는데 있어 중요한 방법 중의 하나로서 물 질을 변형시킬 때 필요한 힘을 나타내는 경도 (hardness)와 부서지는 성질을 나타내는 파쇄성 (brittleness)은 대조구가 처리구들에 비해 저장 1 일 다소 높게 나타났으나, 저장기간에 따른 변화는 크게 나타나지 않았고 처리구들은 저장 기간에 따라 증가하였으며, 저장 40 일 최대값 을 나타내었다. 씹힘성(chewiness)과 검성(gumminess)은 대조구가 처리구들에 비해 낮게 나타 났으며, 저장기간에 따라 모든 구에서 증가하 였으나, 대조구의 증가폭이 가장 작게 나타났 다. 식품의 형태를 구성하는 내부적 결합에 필 요한 힘을 나타내는 응집성(cohesiveness)은 저 장 1 일 대조구가 처리구들에 비해 낮게 나타났 으며, 대조구는 저장기간에 따라 증가하였으나 처리구들은 저장기간에 따른 변화가 없어 저장 40 일에는 대조구가 가장 높은 응집성을 나타내 었다. 물체에 외부로부터 힘을 가한 후 생긴 변형이 힘을 제거 시 원상복귀하는 성질을 나 타내는 탄력성(springiness)은 처리구들에 따른 차이도 나타나지 않았으며 저장기간에 따라 처

Table 3. Changes in water holding capacity(\%) of emulsion-type sausage with functional ingredients during storage at $9 \pm 1^{\circ} \mathrm{C}$

\begin{tabular}{clllll}
\hline \multirow{2}{*}{ Treatment $^{1)}$} & \multicolumn{5}{c}{ Days } \\
\cline { 2 - 6 } & \multicolumn{1}{c}{1} & \multicolumn{1}{c}{10} & \multicolumn{1}{c}{30} & 40 \\
\hline \hline $\mathrm{C}$ & $86.62 \pm 3.93^{\mathrm{AB}}$ & $86.91 \pm 2.72^{\mathrm{AB}}$ & $87.94 \pm 9.58^{\mathrm{AB}}$ & $89.95 \pm 4.47^{\mathrm{A}}$ & $75.55 \pm 8.43^{\mathrm{B}}$ \\
$\mathrm{T} 1$ & $84.72 \pm 3.61^{\mathrm{AB}}$ & $87.30 \pm 10.93^{\mathrm{AB}}$ & $92.74 \pm 10.86^{\mathrm{A}}$ & $86.29 \pm 8.27^{\mathrm{AB}}$ & $72.34 \pm 0.18^{\mathrm{B}}$ \\
$\mathrm{T} 2$ & $84.95 \pm 3.59^{\mathrm{AB}}$ & $90.15 \pm 7.95^{\mathrm{AB}}$ & $81.28 \pm 2.22^{\mathrm{B}}$ & $91.27 \pm 6.83^{\mathrm{A}}$ & $70.70 \pm 0.53^{\mathrm{C}}$ \\
$\mathrm{T} 3$ & $84.70 \pm 6.02$ & $77.92 \pm 9.38$ & $88.72 \pm 8.09$ & $79.11 \pm 8.82$ & $74.19 \pm 1.62$ \\
\hline
\end{tabular}

1) Treatments are the same as described in Table 1.

${ }^{A, B, C}$ Means with different superscripts in the same row are significantly different $(\mathrm{P}<0.05)$. 
Table 4. Changes in texture profile of emulsion-type sausage with functional ingredients during storage at $9 \pm 1^{\circ} \mathrm{C}$

\begin{tabular}{|c|c|c|c|c|c|c|}
\hline \multirow{2}{*}{ Treatment $^{1)}$} & & \multicolumn{5}{|c|}{ Days } \\
\hline & & 1 & 10 & 20 & 30 & 40 \\
\hline \multirow{4}{*}{$\begin{array}{l}\text { Hardness } \\
\text { (kg) }\end{array}$} & $\mathrm{C}$ & $0.39 \pm 0.02^{\mathrm{a}}$ & $0.39 \pm 0.03$ & $0.43 \pm 0.07$ & $0.44 \pm 0.01^{\text {ab }}$ & $0.39 \pm 0.01^{\mathrm{b}}$ \\
\hline & $\mathrm{T} 1$ & $0.38 \pm 0.03^{\mathrm{Ca}}$ & $0.40 \pm 0.05^{\mathrm{C}}$ & $0.47 \pm 0.02^{\mathrm{AB}}$ & $0.41 \pm 0.03^{\mathrm{BCab}}$ & $0.51 \pm 0.02^{\mathrm{Aa}}$ \\
\hline & $\mathrm{T} 2$ & $0.37 \pm 0.02^{\mathrm{Cab}}$ & $0.38 \pm 0.02^{\mathrm{C}}$ & $0.42 \pm 0.04^{\mathrm{BC}}$ & $0.48 \pm 0.06^{\mathrm{ABa}}$ & $0.50 \pm 0.02^{\mathrm{Aa}}$ \\
\hline & $\mathrm{T} 3$ & $0.34 \pm 0.02^{\mathrm{Cb}}$ & $0.37 \pm 0.03^{\mathrm{C}}$ & $0.45 \pm 0.04^{\mathrm{B}}$ & $0.37 \pm 0.01^{\mathrm{Cb}}$ & $0.51 \pm 0.02^{\mathrm{Aa}}$ \\
\hline \multirow{4}{*}{$\begin{array}{l}\text { Chewiness } \\
\text { (g) }\end{array}$} & $\mathrm{C}$ & $249 \pm 10.46$ & $288 \pm 18.74$ & $269 \pm 43.33$ & $324 \pm 30.48^{\mathrm{ab}}$ & $293 \pm 5.60^{c}$ \\
\hline & $\mathrm{T} 1$ & $256 \pm 7.30$ & $319 \pm 23.52$ & $322 \pm 25.48$ & $299 \pm 13.86^{\mathrm{b}}$ & $343 \pm 30.47^{\mathrm{b}}$ \\
\hline & $\mathrm{T} 2$ & $254 \pm 20.06$ & $282 \pm 31.38$ & $307 \pm 39.56$ & $357 \pm 16.59^{\mathrm{a}}$ & $390 \pm 29.48^{\mathrm{a}}$ \\
\hline & $\mathrm{T} 3$ & $251 \pm 47.94^{\mathrm{C}}$ & $262 \pm 66.87^{\mathrm{C}}$ & $353 \pm 44.75^{\mathrm{AB}}$ & $298 \pm 6.13^{\mathrm{BCb}}$ & $417 \pm 25.95^{\mathrm{Aa}}$ \\
\hline \multirow{4}{*}{$\begin{array}{c}\text { Cohesiveness } \\
(\%)\end{array}$} & $\mathrm{C}$ & $49.67 \pm 0.60^{\mathrm{B}}$ & $54.70 \pm 2.19^{\mathrm{AB}}$ & $50.57 \pm 3.70^{\mathrm{Bb}}$ & $54.44 \pm 2.17^{\mathrm{A}}$ & $63.09 \pm 14.71^{\mathrm{AB}}$ \\
\hline & $\mathrm{T} 1$ & $52.59 \pm 2.60^{\mathrm{C}}$ & $57.91 \pm 4.48^{\mathrm{AB}}$ & $53.10 \pm 4.15^{\mathrm{ABab}}$ & $54.30 \pm 1.83^{\mathrm{B}}$ & $51.65 \pm 3.41^{\mathrm{A}}$ \\
\hline & $\mathrm{T} 2$ & $55.21 \pm 2.26^{\mathrm{C}}$ & $54.34 \pm 2.92^{\mathrm{C}}$ & $53.62 \pm 2.73^{\mathrm{BCab}}$ & $54.87 \pm 3.63^{\mathrm{AB}}$ & $57.45 \pm 2.96^{\mathrm{A}}$ \\
\hline & $\mathrm{T} 3$ & $56.49 \pm 9.01$ & $59.67 \pm 1.64$ & $58.60 \pm 1.59^{\mathrm{a}}$ & $57.58 \pm 1.03$ & $60.61 \pm 3.99$ \\
\hline \multirow{4}{*}{$\begin{array}{c}\text { Springiness } \\
(\%)\end{array}$} & $\mathrm{C}$ & $12.99 \pm 0.30$ & $13.53 \pm 0.67$ & $12.35 \pm 0.83^{\mathrm{b}}$ & $13.47 \pm 0.46$ & $12.84 \pm 0.82$ \\
\hline & $\mathrm{T} 1$ & $12.99 \pm 0.17$ & $13.78 \pm 0.34$ & $13.12 \pm 0.50^{\mathrm{ab}}$ & $13.43 \pm 0.75$ & $13.12 \pm 0.71$ \\
\hline & $\mathrm{T} 2$ & $12.63 \pm 0.08^{\mathrm{B}}$ & $13.44 \pm 0.05^{\mathrm{A}}$ & $13.56 \pm 0.45^{\mathrm{Aa}}$ & $13.64 \pm 0.24^{\mathrm{A}}$ & $13.45 \pm 0.23^{\mathrm{A}}$ \\
\hline & $\mathrm{T} 3$ & $12.94 \pm 0.42$ & $12.01 \pm 3.52$ & $13.33 \pm 0.43^{\mathrm{ab}}$ & $13.85 \pm 0.32$ & $13.62 \pm 0.18$ \\
\hline \multirow{4}{*}{$\begin{array}{l}\text { Gumminess } \\
\text { (g) }\end{array}$} & $\mathrm{C}$ & $18.95 \pm 0.26$ & $21.44 \pm 0.97$ & $21.71 \pm 2.12$ & $24.09 \pm 1.48^{\mathrm{ab}}$ & $24.22 \pm 5.29$ \\
\hline & $\mathrm{T} 1$ & $19.77 \pm 0.46^{\mathrm{C}}$ & $23.15 \pm 1.19^{\mathrm{AB}}$ & $24.55 \pm 1.03^{\mathrm{AB}}$ & $22.36 \pm 2.21^{\mathrm{BCb}}$ & $26.22 \pm 2.37^{\mathrm{A}}$ \\
\hline & $\mathrm{T} 2$ & $20.18 \pm 1.67^{\mathrm{C}}$ & $20.98 \pm 2.32^{\mathrm{C}}$ & $22.75 \pm 3.47^{\mathrm{BC}}$ & $26.24 \pm 1.63^{\mathrm{ABa}}$ & $29.04 \pm 1.72^{\mathrm{A}}$ \\
\hline & $\mathrm{T} 3$ & $19.48 \pm 3.99^{\mathrm{C}}$ & $22.14 \pm 1.99^{\mathrm{BC}}$ & $26.45 \pm 2.49^{\mathrm{AB}}$ & $21.54 \pm 0.16^{\mathrm{Cb}}$ & $30.70 \pm 2.28^{\mathrm{A}}$ \\
\hline \multirow{4}{*}{$\begin{array}{l}\text { Brittleness } \\
\text { (g) }\end{array}$} & $\mathrm{C}$ & $0.36 \pm 0.08^{\mathrm{a}}$ & $0.33 \pm 0.02$ & $0.39 \pm 0.08$ & $0.41 \pm 0.02^{\mathrm{ab}}$ & $0.37 \pm 0.01 \mathrm{~b}$ \\
\hline & $\mathrm{T} 1$ & $0.29 \pm 0.01^{\mathrm{Dab}}$ & $0.34 \pm 0.03^{\mathrm{C}}$ & $0.44 \pm 0.02^{\mathrm{B}}$ & $0.39 \pm 0.02^{\mathrm{Bb}}$ & $0.48 \pm 0.03^{\mathrm{Aa}}$ \\
\hline & $\mathrm{T} 2$ & $0.24 \pm 0.01^{\mathrm{Cb}}$ & $0.33 \pm 0.03^{\mathrm{B}}$ & $0.38 \pm 0.03^{\mathrm{B}}$ & $0.47 \pm 0.07^{\mathrm{Aa}}$ & $0.50 \pm 0.02^{\mathrm{Aa}}$ \\
\hline & $\mathrm{T} 3$ & $0.22 \pm 0.03^{\mathrm{Cb}}$ & $0.30 \pm 0.03$ & $0.40 \pm 0.07^{\mathrm{B}}$ & $0.37 \pm 0.01^{\mathrm{BCb}}$ & $0.51 \pm 0.02^{\mathrm{Aa}}$ \\
\hline
\end{tabular}

1) Treatments are the same as described in Table 1.

$\mathrm{A}, \mathrm{B}, \mathrm{C}$ Means with different superscripts in the same row are significantly different $(\mathrm{P}<0.05)$.

a,b Means with different superscripts in the same column are significantly different $(\mathrm{P}<0.05)$.

리구들이 다소 증가하였지만 유의적인 차이는 나타나지 않았다. 따라서 기능성 물질을 첨가 한 처리구들이 저장초기에는 큰 차이를 나타내 지 않았으나 저장기간이 증가함에 따라 경도, 씹힘성, 검성과 파쇄성이 증가하는 것으로 나 타났다.

\section{TBARS}

기능성 물질을 첨가한 유화형소시지의 저장
기간 중 TBARS 변화는 Fig. 1과 같다. TBARS (thiobarbituric acid)는 지방함유 식품의 자동산 화 정도를 측정하기 위해 제안된 이래 식품의 지방 산화상태를 측정하기 위해 가장 널리 사 용되는 방법으로(Tarladgis 등, 1960; Melton, 1983), TBA의 분석결과는 $1 \mathrm{~kg}$ 의 근육 당 지질 과산화물(liquid peroxides)의 분해산물인 malonaldehyde(MA)의 mg으로 나타낸다(Melton, 1983). 생체나 식품 중에 존재하는 불포화지방산은 쉽 게 산화되어 hydroperoxide 등 과산화물을 생성 
Fig. 1. Changes in TBARS of emulsion-type sausage with functional ingredients during storage at $9 \pm 1^{\circ} \mathrm{C}$.

Treatments are the same as described in Table 1.

하여 단백질과 $\mathrm{DNA}$ 에 손상을 주어 돌연변이 및 발암을 유발하며, 동맥경화와 노화를 촉진 하며, 식품의 품질을 저하시킨다. 또한 육제품 의 산패에 따른 TBARS의 생성은 부패취의 생 성과 밀접한 관계가 있어 TBARS의 함량은 육 제품의 신선도를 평가하는 지표가 된다.

저장 1 일 $\mathrm{T} 3$ 구가 다른 처리구에 비해 낮게 나타났으나, 저장기간이 증가함에 따라 처리구 에 따른 차이는 나타나지 않았으며, 저장 40 일 에는 $\mathrm{T} 1$ 이 다소 높은 $\mathrm{TBARS}$ 를 나타내었다. 최
등(2003)은 녹차분말을 첨가하여 소시지를 제조 하였을 때, TBARS가 감소하였는데 이러한 녹 차의 항산화 작용은 활성산소에 의해 불포화지 방산의 과산화 반응이 억제되고, 금속이온에 대한 봉쇄작용도 지니고 있는데 그 주된 인자 는 녹차의 polyphenol 화합물인 catechin류가 관 여하기 때문이라 하였다. 김 등(2002)도 솔잎 및 녹차 추출물을 이용하여 소시지를 제조하였 을 때, 이들의 첨가에 의해 TBARS가 감소하였 다고 하였으나, 본 실험에서는 이들의 첨가로 인한 지방산화 억제효과는 크게 나타나지 않았 다.

\section{5. 육색}

기능성 물질을 첨가한 유화형 소시지의 저장 기간 중 육색의 변화는 Table 5 와 같다. 육제품 의 색은 소비자의 제품 선택 시 기준이 되는 중요한 요인이다. 육색의 밝기를 나타내는 $\mathrm{L}^{*}$ 값은 $\mathrm{T} 2$ 와 $\mathrm{T} 3$ 가 다른 처리구보다 낮게 나타났 으며, 대조구가 높게 나타났다. $\mathrm{T} 2$ 를 제외한 나 머지 처리구들은 저장기간에 따라 $\mathrm{L}^{*}$ 값이 다소 감소하였다. 육색의 적색도를 나타내는 $\mathrm{a}^{\text {*값은 }}$ 대조구가 가장 높게 $\mathrm{T} 2$ 와 $\mathrm{T} 3$ 는 월등히 낮게 나타났다. 다른 $\mathrm{T} 2$ 는 저장기간에 따라 다소 감 소하였지만 다른 처리구들은 증가하는 경향을

Table 5. Changes in color of emulsion-type sausage with functional ingredients during storage at $9 \pm 1^{\circ} \mathrm{C}$

\begin{tabular}{|c|c|c|c|c|c|c|}
\hline \multirow{2}{*}{ Treatment $^{1)}$} & & \multicolumn{5}{|c|}{ Days } \\
\hline & & 1 & 10 & 20 & 30 & 40 \\
\hline \multirow{4}{*}{$\begin{array}{c}\text { Lightness } \\
\left(\mathrm{L}^{*}\right)\end{array}$} & $\mathrm{C}$ & $77.06 \pm 0.54^{\mathrm{Aa}}$ & $75.98 \pm 0.42^{\mathrm{Ba}}$ & $75.82 \pm 0.41^{\mathrm{Ba}}$ & $74.75 \pm 0.37^{\mathrm{Ca}}$ & $75.32 \pm 0.87^{\mathrm{BCa}}$ \\
\hline & $\mathrm{T} 1$ & $74.98 \pm 0.19^{\mathrm{Ab}}$ & $73.50 \pm 0.25^{\mathrm{Bb}}$ & $73.84 \pm 0.25^{\mathrm{Bb}}$ & $73.33 \pm 0.50^{\mathrm{BCb}}$ & $72.82 \pm 0.32^{\mathrm{Cb}}$ \\
\hline & $\mathrm{T} 2$ & $69.91 \pm 1.10^{\mathrm{Ad}}$ & $69.51 \pm 1.42^{\mathrm{ABc}}$ & $69.70 \pm 0.53^{\mathrm{ABd}}$ & $67.76 \pm 1.33^{\mathrm{Bd}}$ & $69.46 \pm 0.49^{\mathrm{ABd}}$ \\
\hline & $\mathrm{T} 3$ & $71.81 \pm 1.02^{\mathrm{ABc}}$ & $70.85 \pm 1.27^{\mathrm{Bc}}$ & $72.47 \pm 0.38^{\mathrm{Ac}}$ & $71.35 \pm 0.30^{\mathrm{ABc}}$ & $70.92 \pm 0.60^{\mathrm{ABc}}$ \\
\hline \multirow{4}{*}{$\begin{array}{c}\text { Redness } \\
\left(\mathrm{a}^{*}\right)\end{array}$} & $\mathrm{C}$ & $7.73 \pm 1.07^{\mathrm{ABa}}$ & $6.94 \pm 1.53^{\mathrm{Ba}}$ & $9.04 \pm 0.11^{\mathrm{Aa}}$ & $6.86 \pm 0.28^{\mathrm{Ba}}$ & $9.18 \pm 0.37^{\mathrm{Aa}}$ \\
\hline & $\mathrm{T} 1$ & $5.46 \pm 0.13^{\mathrm{Ab}}$ & $4.34 \pm 0.78^{\mathrm{Bb}}$ & $5.78 \pm 0.16^{\mathrm{Ab}}$ & $4.49 \pm 0.14^{\mathrm{Bb}}$ & $5.69 \pm 0.09^{\mathrm{Ab}}$ \\
\hline & $\mathrm{T} 2$ & $2.04 \pm 0.06^{\mathrm{Ac}}$ & $0.93 \pm 0.88^{\mathrm{Bc}}$ & $2.11 \pm 0.20^{\mathrm{Ad}}$ & $0.92 \pm 0.48^{\mathrm{Bd}}$ & $1.86 \pm 0.05^{\mathrm{Ad}}$ \\
\hline & $\mathrm{T} 3$ & $2.64 \pm 0.11^{\mathrm{ABc}}$ & $1.99 \pm 0.80^{\mathrm{BCc}}$ & $3.09 \pm 0.03^{\mathrm{Ac}}$ & $1.70 \pm 0.07^{\mathrm{Cc}}$ & $3.05 \pm 0.13^{\mathrm{Ac}}$ \\
\hline \multirow{4}{*}{$\begin{array}{c}\text { Yellowness } \\
\left(b^{*}\right)\end{array}$} & $\mathrm{C}$ & $8.03 \pm 0.85^{\mathrm{d}}$ & $8.69 \pm 0.98^{b}$ & $7.57 \pm 0.10^{\mathrm{d}}$ & $8.65 \pm 0.23^{\mathrm{c}}$ & $7.74 \pm 0.11^{\mathrm{d}}$ \\
\hline & $\mathrm{T} 1$ & $9.01 \pm 0.18^{\mathrm{Cc}}$ & $9.77 \pm 0.79^{\mathrm{ABb}}$ & $9.14 \pm 0.11^{\mathrm{BCc}}$ & $10.22 \pm 0.12^{\mathrm{Ab}}$ & $8.95 \pm 0.11^{\mathrm{Cc}}$ \\
\hline & $\mathrm{T} 2$ & $11.75 \pm 0.45^{\mathrm{Db}}$ & $12.99 \pm 0.49^{\mathrm{Ba}}$ & $12.31 \pm 0.35^{\mathrm{CDb}}$ & $13.72 \pm 0.18^{\mathrm{Aa}}$ & $12.52 \pm 0.04^{\mathrm{BCb}}$ \\
\hline & $\mathrm{T} 3$ & $12.82 \pm 0.23^{\mathrm{Ca}}$ & $13.32 \pm 0.34^{\mathrm{Ba}}$ & $13.27 \pm 0.15^{\mathrm{Ba}}$ & $13.89 \pm 0.04^{\mathrm{Aa}}$ & $13.41 \pm 0.18^{\mathrm{Ba}}$ \\
\hline
\end{tabular}

1) Treatments are the same as described in Table 1.

$A, B, C, D$ Means with different superscripts in the same row are significantly different $(\mathrm{P}<0.05)$.

a,b,c,d Means with different superscripts in the same column are significantly $\operatorname{different}(\mathrm{P}<0.05)$. 
나타내었다. 황색도를 나타내는 $b^{*}$ 값은 대조구 가 가장 낮게, $\mathrm{T} 3$ 가 가장 높게 나타났으며 전 저장기간 동안 그 경향이 유지되었다. 식육의 색은 myoglobin에 의하여 결정되는데 가열육의 육색은 myoglobin의 변성정도에 따라 결정된다. 그러나 myoglobin이 가열에 의하여 변성되면 갈색을 띄게 되지만 염지공정을 거친 육제품은 가열에 의해서도 붉은 색깔이 고정된다. 정 등 (2003)은 깻잎 분말을 첨가하여 소시지를 제조 하였을 때 첨가하지 않은 처리구에 비해 명도 와 적색도는 감소하고 황색도는 증가한다고 하 여 본 실험의 결과와도 일치하였다. 이는 첨가 된 깻잎 분말은 chlorophyll이 함유되어 있어서 녹색을 나타내며 가열, 산, 금속이온 등에 의하 여 변화되어 갈색을 나타낸다고 하였다. 또한 최 등(2003)은 녹차분말을 첨가하여 소시지를 제조하였을 때 소시지의 적색도와 명도를 현저 히 감소시키고 황색도를 증가시킨다고 하여 본 실험의 결과와 일치하였다.

\section{6. 잔존 아질산염}

기능성 물질을 첨가한 유화형소시지의 저장 기간 중 잔존 아질산염의 함량 변화는 Fig. 2과 같다. 염지육의 발색에 대하여 Fox와 Thomson (1964)이 육색의 발색고정 기작을 보고한 이래, Wesley 등(1982)은 발색과 풍미 향상만을 위한 $\mathrm{NaNO}_{2}$ 의 적정 첨가수준은 $50 \sim 100 \mathrm{ppm}$ 으로도 충분하다고 제시하였다. 그러나 Lee와 Song (1983)은 아질산염의 첨가제에 의한 염지육의 풍미 및 육색은 아질산염의 첨가량이 많아질수 록 좋아진다고 하였다. 또한 세균성장 억제효 과에 대하여 연구자들 간에 견해 차이가 있으 나 대부분의 연구자들은 아질산염은 세균의 성 장과 독소생성을 억제시킨다고 하여 이에 필요 한 아질산염의 수준은 150 200 ppm으로 제시하 였다(Buchanan과 Solberg, 1972). 특히 미국에서 는 $\mathrm{Cl}$. botulinum 억제에 필요한 최소량은 150 $\mathrm{ppm}$ 으로 권장하고 있고, 첨가 허용량은 아질산 염 $200 \mathrm{ppm}$, 질산염 $500 \mathrm{ppm}$ 을 초과하지 않도 록 권고하고 있다(Forrest 등, 1975). 그러나 아 질산염을 과잉 첨가시에는 육색을 녹색으로 만 들어 소비자에게 바람직하지 못한 육색을 나타
내며, nitrosamine의 생성(Jeon과 Kim, 1986)을 유리하게 하여 암의 유발을 초래할 수 있다. 이와 같이 아질산염은 천연 식물체에 질산염 상태로 많이 존재하고 있기 때문에 가공 식품 의 아질산염 첨가량을 최소화하여야 하며, 우 리나라 식품위생법규에서는 제품의 잔존량을 $70 \mathrm{ppm}$ 이하로 규정하고 있다.

Fig. 2. Changes in residual nitrite of emulsion-type sausage with functional ingredients during storage at $9 \pm 1{ }^{\circ} \mathrm{C}$.

Treatments are the same as described in Table 1.

본 실험에서는 저장초기에 $\mathrm{T} 3$ 구가 다른 처리 구에 비해 아질산염의 함량이 낮게 나타났으 며, T1은 대조구보다 높은 값을 나타내었다. 저 장 30 일 이후에는 처리구들에서 아질산염의 함 량이 대조구보다도 높은 값을 나타내었으며, 모든 처리구들이 저장기간의 증가에 따라 아질 산염의 함량은 감소하였다. 최 등(2003)은 녹차 분말을 첨가하여 소시지를 제조하였을 때, 아 질산염 함량을 감소시켰으며, 그 첨가량이 높 을수록 잔존량은 감소한다고 하였으나, 김 등 (2002)은 솔잎이나 녹차 추출물을 첨가하여 소 시지를 제조하였을 때, 이들의 첨가가 소시지 의 아질산염 잔류량에 큰 영향을 미치지 않았 는데 이는 녹차의 분말이 아닌 추출물을 사용 하였고 사용 농도에 있어서도 $0.1 \%$ 의 저 농도 로 사용하였기 때문이라고 보고하였다. 하지만 본 실험에서는 분말로 첨가하였으며 그 농도에 있어서도 $0.4 \%$ 를 첨가하였으나, 솔잎 첨가구 (T1)는 대조구와 큰 차이를 나타내지 않아 다소 상이한 결과를 나타내었다. 저장 전 기간 동안 잔존 아질산염은 법적 범위 이내를 유지하였다. 


\section{7. 총세균}

기능성 물질을 첨가한 유화형소시지의 저장 기간 중 총균수의 변화는 Fig. 3 과 같다. 총균 수의 측정은 전반적인 미생물 오염과 위생상 취급의 적부를 판정하는 기준이 되며, 또한 그 후의 세균에 의한 변화를 추정할 수 있다. 저 장 1 일 모든 처리구에서 다소 높은 균수를 나 타내었으며, 저장기간에 따라 증가하였는데 저 장 30 일부터 대조구와 $\mathrm{T} 1$ 의 균수가 높게 나타 났으며, 저장 40 일에는 대조구가 가장 높은 균 수를 나타내었으며 $\mathrm{T} 3$ 가 가장 낮은 균수를 나 타내었고, 모든 처리구에서 $10^{6} \mathrm{CFU} / \mathrm{g}$ 이상을 나타내었다. 우리나라의 경우 식육 제품이나 소시지에 대한 규격기준은 대장균군은 음성, 멸균제품에서는 세균수 음성, 대장균 $\mathrm{O} 157: \mathrm{H7}$ 음성(원료용 분쇄육)으로 되어 있으며, 국제식 품미생물규격위원회(International Committee on Microbiological Specification : ICMSF)에서는 냉 장지육, 냉동식육 및 가공육에 대하여 미생물 규격을 설정하고 있다(한국식품연구소, 1991). Lamkey 등(1991)은 소시지에서 세균 수가 $10^{8}$ $\mathrm{CFU} / \mathrm{g}$ 수준이면 부패 냄새가 나게 되어 식용 이 불가능하다고 하였다. 하지만 본 실험에서 는 저장 40 일차에 $10^{6} \mathrm{CFU} / \mathrm{g}$ 을 나타내었지만 냄새가 심하게 나서 먹기가 어려웠다.

Fig. 3. Changes in total plate count of emulsion-type sausage with functional ingredients during storage at $9 \pm 1{ }^{\circ} \mathrm{C}$. Treatments are the same as described in Table 1 .

\section{8. 유산균}

기능성 물질을 첨가한 유화형소시지의 저장 기간 중 유산균의 변화는 Fig. 4와 같다. 저장 초기에 대조구가 다소 높게 나타났으나, 저장 30 일까지 처리구에 따른 큰 경향은 나타나지 않았으나, 저장 40 일 대조구가 다른 처리구에 비해 월등히 높은 $10^{7} \mathrm{CFU} / \mathrm{g}$ 의 높은 균수를 나 타내었다. 처리구들 중에서는 $\mathrm{T} 3$ 가 다소 낮은 균수를 다음은 T2가 낮은 균수를 나타내었다.

Fig. 4. Changes in Lactobacilli spp. of emulsiontype sausage with functional ingredients during storage at $9 \pm 1^{\circ} \mathrm{C}$.

Treatments are the same as described in Table 1.

9. 관능검사

기능성 물질을 첨가한 유화형소시지의 저장 기간 중 관능검사 변화는 Table 6 과 같다. 색상 은 대조구가 기능성 물질을 첨가한 처리구들에 비해 높게 나타났으며 특히 $\mathrm{T} 2$ 가 가장 낮은 점 수를 나타내었고 저장 30 일까지는 저장기간에 따른 일정한 경향은 나타나지 않았으나 저장 40 일 모든 처리구들의 육색이 감소하였다. 향 은 저장 1 일 $\mathrm{T} 2$ 구가 가장 높은 점수를 나타내 었으며 저장 30 일까지 높은 점수를 유지하였으 나 저장 40일 냄새가 심하게 나면서 $\mathrm{T} 2$ 와 $\mathrm{T} 3$ 구의 점수가 월등히 낮은 점수를 나타내었다. 풍미, 연도, 다즙성은 대조구가 다른 처리구들 에 비해 높게 나타났으며 저장 40 일에는 냄새 가 심하여 측정하지 못했다. 전체적인 기호성 은 저장 1 일에는 $\mathrm{T} 1$ 이 높게 나타났으나 저장 
Table 6. Changes in sensory score of emulsion-type sausage with functional ingredients during storage at $9 \pm 1^{\circ} \mathrm{C}$

\begin{tabular}{|c|c|c|c|c|c|c|}
\hline \multirow{2}{*}{ Treatment $^{1)}$} & & \multicolumn{5}{|c|}{ Days } \\
\hline & & 1 & 10 & 20 & 30 & 40 \\
\hline \multirow{4}{*}{ Color } & $\mathrm{C}$ & $7.5 \pm 1.0^{\mathrm{Aa}}$ & $6.3 \pm 1.0^{\mathrm{AB}}$ & $6.8 \pm 0.5^{\mathrm{ABa}}$ & $5.8 \pm 1.0^{\mathrm{B}}$ & $4.0 \pm 0.8^{\mathrm{C}}$ \\
\hline & $\mathrm{T} 1$ & $7.1 \pm 0.3^{\mathrm{Aa}}$ & $5.8 \pm 0.5^{\mathrm{B}}$ & $5.8 \pm 0.5^{\mathrm{Bb}}$ & $6.0 \pm 0.8^{\mathrm{B}}$ & $4.3 \pm 0.5^{\mathrm{C}}$ \\
\hline & $\mathrm{T} 2$ & $5.3 \pm 1.0^{\mathrm{ABb}}$ & $5.0 \pm 0.0^{\mathrm{AB}}$ & $5.3 \pm 0.5^{\mathrm{ABbc}}$ & $6.0 \pm 0.8^{\mathrm{A}}$ & $4.3 \pm 0.5^{\mathrm{B}}$ \\
\hline & $\mathrm{T} 3$ & $6.3 \pm 1.0^{\mathrm{Aab}}$ & $5.3 \pm 1.5^{\mathrm{AB}}$ & $4.8 \pm 0.5^{\mathrm{ABc}}$ & $5.3 \pm 1.0^{\mathrm{AB}}$ & $3.8 \pm 1.0^{\mathrm{B}}$ \\
\hline \multirow{4}{*}{ Aroma } & $\mathrm{C}$ & $5.8 \pm 1.7$ & $5.8 \pm 1.0$ & $5.5 \pm 1.0$ & $5.3 \pm 1.0^{\mathrm{b}}$ & $4.8 \pm 1.0^{\mathrm{a}}$ \\
\hline & $\mathrm{T} 1$ & $6.0 \pm 2.2$ & $5.3 \pm 0.5$ & $5.3 \pm 0.5$ & $5.8 \pm 0.5^{\mathrm{ab}}$ & $4.8 \pm 1.3^{\mathrm{a}}$ \\
\hline & $\mathrm{T} 2$ & $7.3 \pm 1.0^{\mathrm{A}}$ & $5.8 \pm 1.3^{\mathrm{ABC}}$ & $5.3 \pm 1.0^{\mathrm{BC}}$ & $6.8 \pm 1.3^{\mathrm{ABa}}$ & $4.3 \pm 0.5^{\mathrm{Cab}}$ \\
\hline & $\mathrm{T} 3$ & $5.5 \pm 1.0^{\mathrm{A}}$ & $5.8 \pm 0.5^{\mathrm{A}}$ & $5.8 \pm 1.0^{\mathrm{A}}$ & $5.0 \pm 0.8^{\mathrm{Ab}}$ & $3.3 \pm 0.5^{\mathrm{Bb}}$ \\
\hline \multirow{4}{*}{ Flavor } & $\mathrm{C}$ & $6.3 \pm 1.7$ & $6.0 \pm 1.2$ & $5.8 \pm 1.0$ & $6.3 \pm 1.0^{\mathrm{a}}$ & $-2)$ \\
\hline & $\mathrm{T} 1$ & $6.0 \pm 1.4$ & $5.8 \pm 1.0$ & $6.5 \pm 0.6$ & $6.3 \pm 0.5^{\mathrm{a}}$ & - \\
\hline & $\mathrm{T} 2$ & $6.0 \pm 1.4$ & $6.3 \pm 0.5$ & $5.8 \pm 1.5$ & $5.0 \pm 0.0^{b}$ & - \\
\hline & $\mathrm{T} 3$ & $5.3 \pm 1.0$ & $5.5 \pm 0.6$ & $5.3 \pm 1.3$ & $5.0 \pm 0.8^{\mathrm{b}}$ & - \\
\hline \multirow{4}{*}{ Tenderness } & $\mathrm{C}$ & $6.0 \pm 1.8$ & $6.3 \pm 1.0$ & $6.5 \pm 1.3$ & $6.0 \pm 1.2$ & - \\
\hline & $\mathrm{T} 1$ & $6.3 \pm 1.0$ & $6.3 \pm 0.5$ & $5.8 \pm 0.5$ & $5.8 \pm 1.0$ & - \\
\hline & $\mathrm{T} 2$ & $5.8 \pm 1.0$ & $6.0 \pm 0.8$ & $5.8 \pm 0.5$ & $5.0 \pm 0.0$ & - \\
\hline & $\mathrm{T} 3$ & $6.3 \pm 0.5$ & $5.5 \pm 1.0$ & $5.8 \pm 0.5$ & $5.8 \pm 0.5$ & - \\
\hline \multirow{4}{*}{ Juiciness } & $\mathrm{C}$ & $6.5 \pm 1.7$ & $5.8 \pm 1.0$ & $6.0 \pm 1.4$ & $5.5 \pm 0.6$ & - \\
\hline & $\mathrm{T} 1$ & $6.5 \pm 1.3$ & $5.8 \pm 1.3$ & $5.3 \pm 1.0$ & $5.3 \pm 1.0$ & - \\
\hline & $\mathrm{T} 2$ & $5.8 \pm 1.0$ & $6.0 \pm 1.2$ & $5.5 \pm 0.6$ & $5.5 \pm 0.6$ & - \\
\hline & T3 & $5.0 \pm 1.4$ & $5.3 \pm 1.3$ & $5.5 \pm 1.3$ & $5.0 \pm 0.0$ & - \\
\hline \multirow{4}{*}{$\begin{array}{c}\text { Overall } \\
\text { acceptability }\end{array}$} & $\mathrm{C}$ & $5.5 \pm 1.7$ & $6.0 \pm 1.4^{\mathrm{a}}$ & $6.3 \pm 1.0$ & $6.5 \pm 1.3$ & $5.0 \pm 0.8^{\mathrm{a}}$ \\
\hline & $\mathrm{T} 1$ & $6.0 \pm 0.8^{\mathrm{A}}$ & $5.3 \pm 0.5^{\mathrm{ABab}}$ & $5.8 \pm 1.0^{\mathrm{AB}}$ & $4.8 \pm 1.0^{\mathrm{ABb}}$ & $4.5 \pm 0.6^{\mathrm{Ba}}$ \\
\hline & $\mathrm{T} 2$ & $5.0 \pm 1.4^{\mathrm{A}}$ & $5.5 \pm 0.6^{\mathrm{Aab}}$ & $4.8 \pm 1.0^{\mathrm{A}}$ & $5.8 \pm 1.0^{\text {Aab }}$ & $3.3 \pm 0.5^{\mathrm{Bb}}$ \\
\hline & $\mathrm{T} 3$ & $4.8 \pm 1.0^{\mathrm{A}}$ & $4.3 \pm 0.5^{\mathrm{ABb}}$ & $4.8 \pm 1.0^{\mathrm{A}}$ & $4.8 \pm 0.5^{\mathrm{Ab}}$ & $3.5 \pm 0.6^{\mathrm{Bb}}$ \\
\hline
\end{tabular}

\footnotetext{
1) Treatments are the same as described in Table 1 .

2) Not determined.

${ }^{\mathrm{A}, \mathrm{B}, \mathrm{C}}$ Means with different superscripts in the same row are significantly different $(\mathrm{P}<0.05)$.

${ }^{a, b, c}$ Means with different superscripts in the same column are significantly $\operatorname{different}(\mathrm{P}<0.05)$.
}

10 일부터는 대조구가 높게 나타났는데 이는 육 색, 풍미, 연도, 다즙성 등 거의 모든 항목에서 대조구가 높은 점수를 나타내었기 때문으로 사 료되며 기능성 물질을 분말로 첨가할 경우 첨 가된 분말로 인하여 제품의 육색이 좋지 못한 영향을 미친 것으로 사료된다. 전체적인 기호 도는 저장 30 일차까지 $\mathrm{C}$ 가 5.5 6.5, $\mathrm{T} 1$ 은 4.8 6.0, T2는 4.8 5.8, T3는 4.3 4.8 범위를 나타내 었으며, 실험에 사용된 이들 기능성 물질 첨가 시에는 솔잎, 깻잎 및 녹차분말이 가지는 고유 의 향을 소비자들이 보다 선호하는 풍미로 전환 시키기 위한 향신료의 선정과 함께 이들 기능성 물질의 투입형태나 투입비율 등에 대한 더 많은 연구가 진행되어야 할 것으로 판단된다.
IV. 요 약

본 연구는 기능성 물질인 솔잎분말(T1), 깻잎 분말(T2), 녹차분말(T3)을 각각 $0.4 \%$ 첨가하여 제조된 유화형 기능성 소시지를 $9 \pm 1{ }^{\circ} \mathrm{C}$ 에서 40 일간 저장하면서 10 일 간격으로 품질특성을 조 사하였다. 저장기간이 증가함에 따라 $\mathrm{pH}$ 는 증 가하였다. 저장기간에 따라 모든 처리구에서 보수력이 다소 증가하였으나, 저장 40 일 보수 력이 급격히 감소하였다. 조직감 측정에서 저 장기간이 길어짐에 따라 모든 처리구에서 경 도, 씹힘성, 검성과 파쇄성은 증가하는 것으로 나타났다. TBARS는 저장 1 일에는 $\mathrm{T} 3$ 구가 다른 처리구에 비해 낮게 나타났으나, 저장 40 일에 는 $\mathrm{T} 1$ 이 다소 높은 값을 나타내었다. 육색은 
$\mathrm{T} 2$ 를 제외한 나머지 처리구들은 저장기간에 따 라 $\mathrm{L} *$ 값이 다소 감소하였고, $\mathrm{a}^{*}$ 값은 대조구가 가장 높게, $\mathrm{T} 2$ 와 $\mathrm{T} 3$ 는 월등히 낮게 나타났다. 잔존 아질산염은 저장 전 기간 동안 법적 규정 이내를 유지하였다. 저장 40 일차에 대조구가 가장 높은 유산균수 $\left(10^{7} \mathrm{CFU} / \mathrm{g}\right)$ 를 나타내어 모 든 처리구들 보다 높은 수준이었다. 전체적인 기호도는 저장 30 일차까지 $\mathrm{C}$ 가 5.5 6.5, $\mathrm{T} 1$ 은 4.8 6.0, T2는 4.8 5.8, T3는 4.3 4.8 범위로 나 타났다. 이상의 결과에서 이들 기능성 물질을 함유한 육제품 생산 시에는 솔잎, 깻잎, 녹차분 말의 첨가수준이나 첨가형태 및 사용되는 향신 료 등에 대한 더 많은 연구가 진행될 필요가 있다.

$$
\mathrm{V} \text {.사 사 }
$$

본 연구는 한국과학재단 지정 진주산업대학교 동물생명산업지역협력연구센터(과제번호 : R122002-053-03003-0)의 연구비 지원에 의한 것입 니다.

\section{VI. 인 용 문 헌}

1. Bartholmew, D. T. and Blumer, J. N. 1977. Microbial interactions in country-style hams. J. Food Sci. 42:498.

2. Buchanan, R. L. and Solberg, M. 1972. Interaction of sodium nitrate, oxygen and $\mathrm{pH}$ on growth of Staphylococcus aureus. J. Food Sci. 37:81.

3. Buege, J. A. and Aust, J. D. 1978. Microsomal lipid peroxidation. Methods Enzymol. 52:302.

4. Choi, M Y., Choi, E. J., Lee, E., Rhim, T. J., Cha, B. C. and Park, H. J. 1997. Antimicrobial activities of pine needle(Pinus densiflora seibet Zucc.) Kor. J. Appl. Microbial Biotechnol. 25: 293-297.

5. Choi, O. J. 1991. Yeuakcho seungbun. iyon. Illwelulgak. Seoul. pp. 114-116.

6. Davies M. J., Judd, J. T., Baer, D. J., Clevidence, B. A., Paul, D. R., Edwards, A. J., Wiseman, S. A., Muesing, R. A. and Chen, S. C. 2003. Black tea consumption reduces total and LDL cholesterol in mildly hypercholesterolemic adults. J. Nutr. 133:3298S-3302S.

7. Demeyer, D. I. and Vandekerckhove, P. 1979.
Compounds determining $\mathrm{pH}$ in dry sausage. Meat Sci. 34:351.

8. Forrest, J. C., Aberle, E. D., Hedrick, H. B., Judge, M. D. and Merkel, R. A. 1975. Principles of meat science. H. freeman \& Co. San Francisco. p. 179-180.

9. Fox, J. B. Jr. and Thomson, J. S. 1964. Formation of bovine nitrosylmyoglobin. Biochem. 2:465.

10. Graham, H. N. 1992. Green tea composition, consumption and polyphenol chemistry. Prev. Med. 21:334-350.

11. Jeong, H. G. and Kim, Z. U. 1986. A study on the effects of sodium nitrite on lipid oxidation of pork during cooking. J. Korean Agric. Chem. Soc. 29:148.

12. Khokhar, S. and Magnusdottir, S. G. M. 2002. Total phenol, catechin, and caffeine contents of teas commonly consumed in the United Kindom. J. Agric. Food Chem. 50:565-570.

13. Lamkey, J. K., Leak, F. W., Tiley, W. B., Johnson, D. D. and West, R. L. 1991. Assessment of sodium lactate addition to fresh pork sausage. J. Food Sci. 56:220.

14. Lee, K. I., Rhee, S. H. and Park, K. Y. 1999. Anticancer activity of phytol and eicosatrienoic acid identified from perilla leaves. Kor. J. Soc. Food Sci. Nutr. 28:1107-1112.

15. Lee, S. K. and Song, K. W. 1983. Effects of different levels of sodium nitrite, ascorbic acid and sodium chloride on characteristics of ground meat. J. Anim. Sci. \& Technol.(Kor) 25:288-295.

16. Melton, S. L. 1983. Methodology for following lipid oxidation in muscle foods. Food Technol. 37:105.

17. Mercurio, K. C. and Behm, P. A. 1981. Effect of fiber type and level on mineral excretion transit time and intestinal history. J. Food Sci. 46:14621463.

18. Moon, J. J., Han, Y. B. and Kim, J. S. 1993. Studies on antitumor effects of pine needless, Pinus densiflora Sieb. et Zucc. Kor. Vet. Res. 33: 701-710.

19. Nam, J. H., Song, H. I., Park, C. K., Moon, Y. H. and Jung, I. C. 2000. Quality characteristics of pork patties prepared with mugwort, pine needle and fatsia leaf extracts, Kor. J. Life Sci. 10:326.

20. Park, C. S. Kwon, C. J., Choi, M. A., Park, G. S. and Choi, K. H. 2002. Antioxidative and nitrite scanvenging activity of mugwort and pine needle extracts. Kor. J. Food Preservation. 9:248-252. 
21. Park, D. S., Lee, K. I. and Park, K. Y. 2001. Quantitative analysis of dietary fibers from Perilla fruteuscens seeds and antimutagenic effect of its extracts. J. Kor. Soc. Food Sci. Nurt. 30:900-905.

22. Park, J. K. 1984. Hanbang daewejeun. Dongyang jonghab tonsingyoykweon. Daegu. p. 134-136.

23. Robak, J. and Gryglewski, R. J. 1998. Flavonoids are scanvengers of superoxide anions. Bicochemical Pharmacology. 37:837-841.

24. SAS. 1999. SAS/STAT Software for PC. Releasw 6.11, SAS Institute, Cary, Nc, U. S. A.

25. Shi, J. 2002. Bioavailability and efficiency of tea catechins as an antioxidant. Neutraceut. Food. 7:327-331.

26. Tada, M., Matsumpto, R., Yamaguchi, H. and Chiba, K. 1996. Novel antioxidants isolated from Perilla fruteuscens Britton var. crisp (Thunb.) Biosci. Biotech. Biochem. 60:1093-1095.

27. Tarladgis, B. G., Watts, B. M., Younathan, M. T. and Dugan, L. R. Jr. 1960. A distillation method for the quantitative determination of malonaldehyde in rancid food. J. Am. Oil Chem. Soc. $37: 44$.

28. Toyoda, M., Tannk, K., Hoshimo, K., Akiyama, H., Tanimura, A. and Saito, Y. 1997. Profiles of potentially antiallergic flavonoids in 27 kinds of health tea and green tea infusions. J. Agric. Food Chem. 45:2516-2564.

29. Wesley, R. L., Marion, W. W. and Sebrandek, J. G. 1982. Effects of sodium nitrite concentration sodium erythorbate and storage time on the quality of Franks Manufactured from Mechanically Deboned turkey. J. Food Sci. 47:1626.

30. Yang, C. S. and Landau, J. M. 2002. Effects of tea consumption on nutrition and health. J. Nutr. 130:2127-2130.

31. Yang, T. T. and Koo, M. W. 1997. Hypocholesterolemic effects of Chinese tea. Pharmacol Res. 35:505-512.

32. Yoon, S. O., Yoo, S. J. and Oh, J. S. 1997. A study on the pharmacological and nutritional values of needle of pinus densiflora $\mathrm{S}$. et $\mathrm{Z}$. Research Bulletin of the Experiment Foresta. 5: 63-81.

33. 김소영, 정석문, 이승철. 2004. 원적외선 처리가 녹차의 항산화능과 카테킨 함량에 미치는 영향. 한국식품영양과학회지. 33:753-756.

34. 김수민, 조영석, 성삼경, 이일구, 이신호, 김대곤. 2002. 솔잎 및 녹차 추출물을 이용한 기능성 소 시지개발. 한국축산식품학회지. 22:20-29.
35. 김수민, 조영석, 성삼경, 이일구, 이신호, 김대곤. 2002. 솔잎 및 녹차추출물의 항산화성 및 아질산 염 소거작용. 한국축산식품학회지. 22:13-19.

36. 김은성, 김미경. 1999 . 감잎, 녹차, 솔잎의 건분 및 에탄올추출물이 흰쥐의 지방대사와 항산화에 미치는 영향. 한국영양과학회지. 32:337-352.

37. 박금순, 이선주, 정외숙. 2002. 당의 종류와 녹차 가루 첨가량에 따른 육포의 품질특성. 한국식품 영양과학회지. 31:230-235.

38. 백태홍, 이민수, 이준흥. 1991. 송엽중의 항산화 성 물질이 리놀산의 광산화에 미치는 영향. 한국 유화학회지. 4:25-30.

39. 오승희, 김용욱, 김명애. 2004. 율피, 솔잎, 호프 의 아세톤 추출물의 항산화작용. 한국식생활문화 학회. 19:399-406.

40. 이 은. 2003. 솔잎분말이 과산화지질을 급여한 흰쥐의 혈장 및 간장의 지질구성과 항산화능에 미치는 영향. 한국식품영양과학회지. 32:926-930.

41. 이 은, 최무영. 2000. 솔잎분말이 고 콜레스테롤 급여 흰쥐의 체지질구성과 TBARS량에 미치는 영향. 한국영양과학회지. 32:337-352.

42. 이종섭, 박경옥. 1996. 송엽 추출물을 이용한 카 드뭄 독성의 해독에 관한 연구. 한국환경위생학 회지. 22:88-97.

43. 정인철, 강세주, 김종기, 현재석, 김미숙, 문윤희. 2003. 깻잎 분말 첨가와 도체 등급이 도육 소시 지의 품질 및 기호성에 미치는 영향. 한국식품영 양과학회지. 32:350-355.

44. 진현화, 양정례, 정종화, 김양하. 2004. 고 콜레스 테롤 식이 투여 흰쥐에 있어서 녹차의 콜레스테 롤 저하효과. 한국식품영양과학회지. 33:47-51.

45. 최성희, 권혁추, 안덕준, 박정로, 오동환. 2003. 녹차분말 첨가 소시지의 아질산염 잔유량과 저 장성. 한국축산식품학회지, 23:299-308.

46. 한국식품연구소. 1991. 식품위생관련 국제식품규 격 및 제외국의 규격기준에 관한 연구. p. 1056-1062.

47. 허승원, 배수미, 한찬희, 최지향, 김종국, 박은경, 노덕영, 이준모, 남궁석은, 안웅식. 2004. 난소암 세포주에서 녹차 추출물의 항암작용. 대한산부인 과학회지. 47:634-649.

48. 현광옥, 김재호, 송기진, 이종복, 장정호, 김영선, 이종수. 2003. 온실재배와 노지 재배한 금산 깻 잎의 생리기능성. 한국식품과학회지. 35:975-979.

49. 홍근택, 이용림, 임무현, 정낙현. 2004. 솔잎발효 추출물의 효소적 저해활성 및 아질산염 소거작 용. 한국식품저장유통학회. 11:94-99.

(접수일자 : 2005. 4. 1. / 채택일자 : 2005. 7. 21.) 